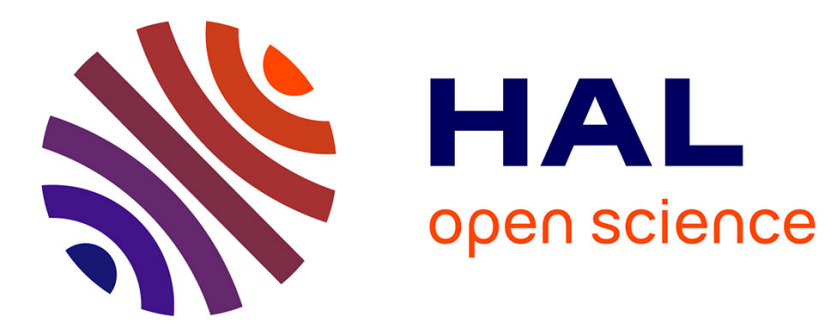

\title{
What are "opossum-like" fossils? The phylogeny of herpetotheriid and peradectid metatherians, based on new features from the petrosal anatomy
}

Sandrine Ladevèze, Charlène Selva, Christian de Muizon

\section{- To cite this version:}

Sandrine Ladevèze, Charlène Selva, Christian de Muizon. What are "opossum-like" fossils? The phylogeny of herpetotheriid and peradectid metatherians, based on new features from the petrosal anatomy. Journal of Systematic Palaeontology, 2020, 18 (17), pp.1463 - 1479. 10.1080/14772019.2020.1772387 . hal-03424217

\section{HAL Id: hal-03424217 https://hal.science/hal-03424217}

Submitted on 16 Nov 2021

HAL is a multi-disciplinary open access archive for the deposit and dissemination of scientific research documents, whether they are published or not. The documents may come from teaching and research institutions in France or abroad, or from public or private research centers.
L'archive ouverte pluridisciplinaire HAL, est destinée au dépôt et à la diffusion de documents scientifiques de niveau recherche, publiés ou non, émanant des établissements d'enseignement et de recherche français ou étrangers, des laboratoires publics ou privés. 
Journal of Systematic Palaeontology

\title{
Title page
}

\section{What are "opossum-like" fossils? The phylogeny of herpetotheriid and peradectid metatherians, based on new features from the petrosal anatomy}

Sandrine Ladevèze, Charlène Selva, Christian de Muizon

CR2P Centre de Recherche en Paléontologie, Paris, UMR 7207, CNRS - MNHN - Sorbonne Université, 8 rue Buffon CP38, F-75005 Paris

sandrine.ladeveze@mnhn.fr

\begin{abstract}
The phylogenetic relationships of "opossum-like" metatherians, Herpetotheriidae and Peradectidae, remain debated; and yet they are key taxa in the evolutionary history of the crown Marsupialia. With state-of-the-art technologies of X-ray microtomography (CT-Scan), it is now possible to access the inner anatomy of the skull and particularly the ear region, which is more and more frequently used in phylogenetic analyses.

Here we describe for the first time the petrosal and inner ear anatomy of the type species Peratherium elegans from the early Oligocene of Ronzon, together with Amphiperatherium elegans from the Eocene of the Montmartre Gypsum. A parsimony analysis of cranial (including petrosal), dental, and postcranial characters in 25 metatherians (extant and fossil
\end{abstract}


taxa including the four herpetotheriids of the study) does not support inclusion of herpetotheriids or peradectids within Didelphimorphia. The results indicate the monophyly of Peratherium cuvieri, P. elegans and A. minutum, but the other herpetotheriid of the analysis, Herpetotherium cf. fugax, is more closely related to the crown clade Marsupialia. Peradectids and herpetotheriids, traditionally considered as "opossum-like", are here respectively stemmetatherians and stem-marsupials. The hypothesis in favour of an ancient origin of opossums (Didelphidae) is therefore questioned.

\section{Keywords}

Herpetotheriidae - Metatheria - CT-Scan - Comparative Anatomy - Auditory region Phylogeny -

\section{Introduction}

Herpetotheriids are considered as a key taxon in the evolutionary history of Metatheria (clade of therian mammals comprising marsupials and all taxa closer to opossums than to placentals) and particularly in the origin of opossums (Didelphidae) (Sánchez-Villagra et al. 2007; Horovitz et al. 2008). Herpetotheriids include fossil metatherians whose dentition is considered "opossum-like". They are documented in North America, Europe, Asia, Africa and possibly in South America, from the Late Cretaceous to the Miocene (see Goin \& Candela 2004; Sánchez-Villagra et al. 2007; Oliveira \& Goin 2012; Ladevèze et al. 2012).

The concept of "opossum-like" metatherians is structural rather than phylogenetic, uniting herpetotheriids and peradectids, with no phylogenetic basis. It is actually based on the overall 
morphological resemblance with extant opossums, which is, by many aspects, plesiomorphic. While traditionally referred to didelphid marsupials or didelphimorphians (e.g. Reig et al. 1987; Goin 1991; Kirsch et al. 1997), herpetotheriids were found as closely related to the crown Marsupialia while peradectids were included in Didelphimorphia (i.e., the clade that comprises Didelphidae and any fossil more closely related to Didelphis than to Dromiciops) in a first cladistic analysis of the phylogenetic affinities of "opossum-like" taxa (Horovitz et al. 2009). In his review of European herpetotheriids, Crochet (1980) included the latter in the Didelphinae, but suggested they were originating from an early offshoot of South American Late Cretaceous "opossum-like" taxa. The didelphimorphian affinities of herpetotheriids were nonetheless questioned by some (Reig et al. 1987; Kirsch et al. 2007), invoking an independent origin from a peradectid stock and dental convergences with didelphids. In the Palaeogene of Europe, across the "Grande Coupure", both herpetotheriids and peradectids were abundant and well documented in the fossil record, with almost complete skulls and partial skeletons. It is commonly accepted that European and North American herpetotheriids are very similar with respect to their dental morphology, hence justifying the hypothesis of pathways and dispersals between the two continents. However, their skull anatomy, which has not been studied in details so far, is likely to convey different data and the overall morphological resemblance of European and North American herpetotheriids has to be questioned. European herpetotheriids are represented by two genera, Peratherium and Amphiperatherium, the molar morphology of which being so similar that it has raised the question of a putative synonymy (Ladevèze et al. 2012). Here again, the skull anatomy is likely to bring crucial information solving the discrepancy or similarity of the two genera. As far as the European herpetotheriids are concerned, only a fragmented skull with almost complete petrosals of Peratherium cuvieri (Selva \& Ladevèze 2017) has been thoroughly described and compared to the well-preserved skull and petrosal bone of the North American 
Herpetotherium cf. fugax (Sánchez-Villagra et al. 2007; Horovitz et al. 2008). Here we describe, thanks to X-Ray Tomography (CT-scan), the 3D model of the petrosal bones of the two palaeogene European herpetotheriids Peratherium elegans, the type-species, and Amphiperatherium minutum. Anatomical features of their skull are coded in a morphological matrix including dental, cranial and postcranial characters, verified in selected metatherians. The cladistic analysis offers an interesting hypothesis in which Herpetotheriidae is paraphyletic, and Amphiperatherium and Peratherium form a clade. Many characters gather the two European genera but they differ in their petrosal anatomy. Our result provides a new direction for addressing crucial questions about metatherian biogeography.

\section{Material and Methods}

\section{Institutional Abbreviations}

MNHN-GY, Montmartre Gypsum Collections, Muséum national d'Histoire naturelle, Paris; PAR, Musée Crozatier, Puy-en-Velay; ZMB, Museum für Naturkunde, Berlin; USNM, United States National Museum of Natural History, Washington.

\section{Material}

Herpetotheriidae. Two unpublished herpetotheriid petrosal bones are described here. 1) Peratherium elegans, from the early Oligocene of Ronzon, France, is the type species of the genus Peratherium and is represented by a skull, associated to partial postcranial skeleton (PAR 39.22, Musée Crozatier, Puy-en-Velay, France). The skull bones are broken up but the right petrosal is preserved. 2) Amphiperatherium minutum, from the Eocene Montmartre Gypsum Formation (Paris Basin, France), is represented by a remarkably preserved skull (see 
Crochet 1981: fig. 71 and P1.2a, b), to which is interlocked the mandible [MNHN-GY-682 (previous number: Cuvier collection MNHN 7912)]. The right petrosal is preserved. It is noteworthy that this specimen is a juvenile, with a dental ontogenetic stage characterised by an upper deciduous premolar dP3 and no M3 erupted, and a lower deciduous dp3 and a m3 erupted (pers.obs.). Some of the observed characters can therefore be age-related.

Both taxa are compared to the recently described Peratherium cuvieri from the Montmartre Gypsum (Selva \& Ladevèze 2017). The holotype specimen (MNHN-GY-679: main and counterpart slabs, plus two mandibular fragments) contains the right petrosal. Herpetotherium cf. fugax has been previously described and coded for a phylogenetic analysis (SánchezVillagra et al. 2007; Horovitz et al. 2008). The 3D model of the left petrosal of this species (ZMB 50672) has been included in this study.

Peradectiidae. Only one peradectid is known by its petrosal bone: Mimoperadectes houdei (Horovitz et al. 2009) (right petrosal, USNM 482355).

\section{Comparative anatomy}

The petrosal bone and bony labyrinth of the inner ear of Peratherium elegans is here thoroughly described and compared to Peratherium cuvieri (Selva \& Ladevèze 2017), in order to highlight basic resemblances and differences. Anatomical nomenclature mostly follows Wible (2003), Ladevèze \& Muizon (2007, 2010), Selva \& Ladevèze (2017). Consecutively, the anatomy of the petrosal and bony labyrinth of Amphiperatherium minutum is more generally described, focussing on resemblances and differences with other herpetotheriids (P. elegans, P. cuvieri, and Herpetotherium cf. fugax).

\section{CT-Scanning and 3D rendering}


Micro-CT technology was used to extract information from the specimens of Peratherium elegans (PAR 39.22) and Amphiperatherium minutum (GY682) regarding the otherwise inaccessible anatomical structures hidden in the matrix.

For the specimen PAR 39.22, CT scanning was conducted in April 2014 at the X-ray Tomography Imagery Platform AST-RX of the MNHN, using a GE Sensing and Inspection Technologies phoenix|x-ray v|tome|x L240-180 CT scanner. The scan was made with an isotropic voxel size of $23.42520 \mu \mathrm{m}$ under a voltage of $85 \mathrm{kV}$ and a current of $270 \mu \mathrm{A} .1400$ projections over 360 degrees with different exposure time were used, with three averaged images per projection and one skipped image before each projection. The data were reconstructed using phoenix datos|x1 2.0 reconstruction software, and then exported into a 16bit TIFF image stack.

Concerning the specimen GY682, CT-scanning was conducted at the University Center for Quantitative X-ray Imaging (PennState). 1190 projections over 360 degrees were performed with an isotropic voxel size of $75 \mu \mathrm{m}$ under a voltage $160 \mathrm{kV}$ and a current of $0.2 \mathrm{~mA}$. For both specimens, post-processing was carried out at the Paleontology Imaging Unit of the MNHN Department Origines et Évolution/CNRS UMR 7207. In order to optimize the postprocessing, the stack was cropped, corrected (level balance, brigthness/contrast), and converted in 8 bits with ImageJ software (Abramoff, Magalhães \& Ram, 2004) for final image stacks. Mimics ${ }^{\circledR}$ v.17.00 (Materialise) was used for the 3D-modelling (segmentation and 3D-object rendering).

\section{Phylogenetic analysis}

We combine the last updated morphological matrices, originally built to evaluate the parsimony relationships within Marsupialiformes (see Supplementary Material 1 for the 
complete list of morphological characters, based on the works of Horovitz et al., 2009;

Ladevèze \& Muizon 2010; Sánchez-Villagra et al. 2007; Beck, 2012; Forasiepi et al. 2015;

Muizon et al., 2018), which we adapted to our subject of study, after a comparative study of specimens and casts.

In the final matrix 28 taxa were scored for 78 dental, 11 mandibular, 99 cranial, and 98 postcranial characters. Of the multistate characters, 23 were coded as ordered. Polymorphic taxa were coded with multiple character state entries. We scored all observable characters for Amphiperatherium minutum, but given its young ontogenetic age (persistence of decidual premolar, non-eruption of M3 and m4), some of these scorings have to be taken cautiously. The three outgroup taxa are fossil eutherians, the sister group to Metatheria, and are represented by at least cranial remains from the Cretaceous of Mongolia: Prokennalestes (upper and lower postcanine teeth, dentaries and one petrosal, Maelestes (skull, mandible and anterior vertebrae and partial left forelimb), and Asioryctes (several complete skulls and skeletons). Ingroup taxa include metatherians that belong to different lineages. The interest group of the present study, Herpetotheriidae (represented by the four species introduced above), are compared to other well-preserved fossil metatherians (pucadelphyids, stagodontids, peradectids, deltatheridiids, Kokopellia, and Asiatherium), and selected Recent marsupials amongst the least derived clades (didelphids, Dromiciops, dasyurids). The comparative specimens that were scored for the cladistic analysis are the same than those used in the analysis of Muizon et al. (2018).

The taxon/character states matrix (Supplementary Material 2) was analysed using heuristic parsimony searches implemented by PAUP* (Swofford, 2002). Each heuristic parsimony search employed 1000 replicates of random taxon addition with TBR branch swapping, saving up to 10 trees. Branch support was assessed by calculating the decay Bremer index 
(Bremer, 1988) with PAUP* (Swofford, 2002). The resulting strict consensus tree with morphological character states optimizations is generated by PAUP* (Swofford, 2002).

\section{Systematic palaeontology}

Mammalia Linnaeus, 1758

Theria Parker and Haswell, 1897

Metatheria Huxley, 1880

Notometatheria Kirsch, Lapointe, and Springer, 1997

Herpetotheriidae (Trouessart, 1879)

Peratheriinae subfam.nov.

Type Genus. Peratherium Aymard, 1850.

Type Species. Peratherium elegans (Aymard, 1846).

Genera included. Peratherium and Amphiperatherium.

Peratherium Aymard, 1850

Peratherium elegans (Aymard, 1846)

(Fig. 1)

Lectotype. B33 Aymard Collection, Musée Crozatier from Le Puy-en-Velay, France: right mandible with $\mathrm{p} 1-\mathrm{m} 4$, left mandible with $\mathrm{p} 3-\mathrm{m} 2$, right humerus and radius, axis. Type locality. Ronzon, France.

Age. Early to middle Oligocene.

Emended diagnosis (modified from Crochet 1980). We review here the diagnosis proposed by Crochet (1980) by indicating the variable characters and adding the synapomorphies resulting from the present cladistic analysis. P. elegans is a medium-sized species, but generally larger than P. cuvieri. Its dental morphology is very similar to that of P. cuvieri. It is characterised 
by: upper molars increasing in size from M1 to M3, ectoflexus sometimes deep and asymmetrical essentially on M3 (although this feature is very variable, it can even be absent in some specimens), metastylar area expanded on M3; stylar cusp B subequal or larger than stylar cusp D, paracone smaller than metacone, lower molars increase in length from $\mathrm{m} 1$ to $\mathrm{m} 3$, anterior end of cristid obliqua beneath or labial to carnassial notch, talonid of $\mathrm{m} 4$ sometimes very long but relatively shortened in width with reduction of the postcristid. P. elegans differs from $P$. cuvieri by: stylar cusp C more prominent (indistinguishable in $P$. cuvieri), ectoflexus shallower, preparacrista ending between the stylar cusps A and B (it ends at stA in $P$. cuvieri), protocone strongly projected anteriorly.

P. elegans differs from other Peratheriinae by the sagittal crest present and restricted to parietals.

\section{Anatomical description of the petrosal bone}

The petrosal bone of PAR 39.22 (P. elegans) is poorly preserved, especially in its tympanic area, as much as the entire skull is. Nevertheless, CT scanning has allowed a 3D reconstruction of the intracranial aspect of the bone and of the bony labyrinth, which are well preserved and described below (Fig. 1 and Supplementary Material 3).

Tympanic view. The petrosal is composed of two major divisions: the pars cochlearis, which consists in the promontorium and houses the cochlear duct and saccule of the inner ear; and the pars canalicularis, which consists in the rest of the petrosal and houses the semicircular canals and utricle.

The overall shape of the petrosal in this view is similar to that of P. cuvieri. The teardropshaped promontorium is broken and the internal coiling of the cochlea is therefore visible. Its 
base is large, approximately as wide as its height, and its apex stretches anterolaterally. The broader, posterior part of the promontorium extends anteromedially in a thinner edge, the anteromedial flange. On the lateral area of the latter is a very shallow fossa that likely accommodated the tensor tympani muscle. On the posteroventral region and medially placed, is a tiny tubercle, the rostral tympanic process of the petrosal. Posterodorsal to the rostral tympanic process is a very damaged area, which should have contained the external aperture of the cochlear fossula (fenestra cochleae), covered in life by the secondary tympanic membrane. Dorsomedially extends a thick edge that separated the fenestra cochleae from the aquaeductus cochlearis (or external aperture of cochlear canaliculus), which transmitted the perilymphatic duct into the petrosal. The posterolateral part of the promontorium is somewhat better preserved and exhibits a small oval-shaped, although broken, fenestra vestibuli, which housed the footplate of the stapes. Its damaged contours however prevent from any estimation of the stapedial ratio (maximal length/width). Lateral to the fenestra vestibuli is a small opening, the secondary facial foramen, from which exited the hyomandibular branch of the facial nerve into the facial sulcus. The facial sulcus is not visible here, but should have ran along the posterior limits of the promontorium, up to the stylomastoid notch. As observed in P. cuvieri, the secondary facial foramen is bordered posterolaterally by the petrosal tympanic crest (sensu Muizon et al., 2018) which forms the anterior border of an elongated depression found in the posterior part of the lateral flange of the pars canalicularis. This depression is bordered posterolaterally by the squamosal and is composed of the epitympanic recess and the fossa incudis, which housed the ossicles in life. The broadest anterolateral fossa is the epitympanic recess, which received the incudomalleolar articulation (Klaauw 1931). The deepest posteromedial pit is the fossa incudis, which housed the crus breve of the incus. The tympanic petrosal crest is sharp and forms the floor of the tympanic aperture of the prootic canal. As is observed in extant didelphids it is strongly oblique dorsoventrally, its lateral end 
being much more ventral than its medial one. A well-developed and bulged tuberculum tympani is observed on its lateral end, a condition also present in P. cuvieri but that differs from extant didelphids, in which it expands into an anteroventrally and triangular process. The prootic canal conveys the prootic canal vein onto the tympanic surface of the petrosal. The prootic canal vein connects the prootic sinus to the lateral head vein, which runs in the facial sulcus and joins further medially the inferior petrosal sinus to form the internal jugular vein in metatherians (Wible 1990; Wible \& Hopson 1995; Ladevèze \& Muizon 2007; Wible et al. 2009). The prootic canal has been reported as absent in Herpetotherium cf. fugax (SánchezVillagra et al., 2007; Horovitz et al., 2008) but a reinvestigation of the CT images reveals the presence of a small canal for the prootic canal vein (pers. obs.; Supplementary Material 5). Both the epitympanic recess and fossa incudis are medially bordered by the crista parotica, which is curved and U-shaped (vertically). Medially to the fossa incudis, the crista parotica is surmounted by a pointed tubercle, the tympanohyal, which has a cartilaginous articulation with the stylohyal. Just medial to it, a tiny indentation marks the stylomastoid notch, for the facial nerve exit from the middle ear. In both $P$. elegans and $P$. cuvieri, the tympanohyal and stylomastoid notch are poorly developed. The stylomastoid notch is somewhat hidden by a broad -although broken- process, the mastoid process, which projects posteroventrally and is exposed on the occiput. Medial to the mastoid process and on the posterior edge of the facial sulcus is a thin blade of bone, the caudal tympanic process of petrosal, which extends towards the position of the jugular foramen between the basioccipital, exoccipital, and petrosal. Between the stylomastoid notch laterally and the edge of the jugular foramen medially, a deep sulcus posteriorly borders the promontorium. It is mostly hidden ventrally by the anterodorsal projection of the caudal tympanic process and comprises a deep pit for the stapedius muscle, the stapedial fossa and, medially to it, the shallow and narrow postpromontorial tympanic sinus (sensu Wible 1990). 
A similar condition is observed in $P$. cuvieri. The mastoid process of $P$. elegans forms a lateral wall for a large surface of bone, the mastoid exposure, which is exposed on the occiput and wedged between the squamosal, supraoccipital, and exoccipital. The lateralmost part of the pars canalicularis is almost smooth, there is no trace of any postpromontorial sulcus for the diploetic vessels, as in $P$. cuvieri.

Cerebellar view. The cerebellar surface of the petrosal is dominated by two excavations: anteriorly is the internal acoustic meatus (IAM), and posteriorly and separated from it by a broad shelf of bone is the fossa subarcuata (FSA), which accommodates the parafocculus of the cerebellum.

The IAM has a lemniscate or figure-eight shape. It is shorter and shallower than the FSA, but its diameter is subequal to that of the FSA, contrary to P. cuvieri in which the anterior apex of the petrosal is more pointed and the IAM consequently is less expanded. It is characterized by two openings separated by a transverse septum, broken but apparently broad. The medial opening, the foramen acusticum inferius, transmitted two branches of the vestibulocochlear nerve (VIII) to the internal substance of the petrosal: the cochlear branch through an anteriorly directed canal (tractus spiralis foraminosus of Meng \& Fox 1995), which must have led into the damaged anteromedial area of the IAM, and the vestibular branch through the posteriorly directed canal (foramen singulare of Meng \& Fox 1995). The lateral aperture, the foramen acusticum superius, conveyed the facial nerve (VII) and one branch of the vestibulocochlear nerve (Wible 1990). The ICA is bordered laterally by a thick rim of bone, the prefacial commissure, under which ran the facial nerve into the geniculate ganglion. Anteriorly to the ICA and similarly to $P$. cuvieri, is a large and deep groove, lying on the anterodorsal apex of the petrosal and directed lateromedially. It is the sulcus for the inferior petrosal sinus, which exited through the jugular foramen. Posteriomedial to the posterior end 
of the sulcus for the inferior petrosal sinus is a circular fossa with a round foramen in the middle of it, the aperture of the cochlear canaliculus, through which passed the perilymphatic duct. More posterior to it is a slit-like opening, the aperture of the vestibular aqueduct, for the endolymphatic duct.

Posteriorly to the IAM, the FSA forms a large and deep cylindrical excavation. It is delimited by the underlying three semicircular canals, the anterior and posterior joining at the crus commune inside the medial wall of the FSA. The anterior semicircular canal underlyies inside the posterolateral border of the FSA. The lateral semicircular canal forms the internal anteroventral wall of the FSA.

Lateral view. The FSA is anterolaterally delimited by the crista petrosa. The latter forms a thick edge, which marks the separation from an anteroventrally directed bony wing, interpreted as a relic of the anterior lamina of non-therian mammals, which most likely received a part of the trigeminal ganglion (see Marshall \& Muizon 1995; Ladevèze \& Muizon 2007, 2010; Selva \& Ladevèze 2017; Muizon et al. 2018). For a discussion on the occurrence of an anterior lamina in certain metatherians, we refer here to the detailed studies of Marshall \& Muizon (1995: 78-82) and Muizon et al. (2018: 408) on Pucadelphys and Allqokirus respectively. The provided arguments to support the interpretation of the structure housing the trigeminal ganglion as being a vestigial anterior lamina are followed here, although they are against Rougier \& Wible (2006)'s interpretation. A vestigial anterior lamina is also observed in P. cuvieri. On the specimen of P. elegans under study (PAR 39.22) the anterior lamina is clearly less developed than in P. cuvieri, a condition that may be the result of incomplete preservation of this structure on the specimen.

At the posteromedial corner of the FSA and extending up to the aperture of the vestibular aqueduct, is a short groove for the sigmoid sinus, a branch of the transverse sinus. In extant 
marsupials, the transverse sinus is one dural venous sinus that distributes the superior petrosal sinus, which runs to the cavernous sinus, the prootic sinus, and the sigmoid sinus onto the cerebellar surface of the petrosal bone (see Wible 2003). As in P. cuvieri, the division of the transverse sinus into the superior petrosal sinus is visible on the posterolateral corner of the FSA. Beyond the origin of the superior petrosal sinus, the transverse sinus divides into two larger branches: the prootic sinus anteriorly and the sigmoid sinus medially. The sulcus for the prootic sinus is broad on the anteroventral apex of the vestigial anterior lamina and is better seen in lateral view. In extant marsupials, the prootic sinus runs ventrally between the petrosal and squamosal and ultimately leaves the skull as the postglenoid vein via the postglenoid foramen in the squamosal. A very tiny lateral aperture for the prootic canal received a small vein that connected with the rudimentary lateral head vein on the tympanic side of the petrosal.

\section{Anatomical description of the bony labyrinth of the inner ear}

The bony labyrinth of the inner ear consists of a set of interconnected spaces within the petrosal bone. It contained in life the perilymph, in which the membranous labyrinth - a series of soft-tissue sacs and ducts- was suspended. The inferior part of the membranous labyrinth includes the cochlear duct, which contains the spiral organ of hearing, and the saccule of the vestibule, which contains receptors sensitive to linear motion. The superior part of the membranous labyrinth is involved in detecting rotational movement of the head; it includes the utricle of the vestibule, the semicircular ducts and ampullae, and the common crus between the anterior and posterior ducts. The bony semicircular and cochlear canals of the bony labyrinth are usually considered as closely following the path and shape of the inner membranous ducts (e.g., Blanks et al. 1975; Spoor 2003; David et al. 2010). 
Because the promontorium of $P$. elegans is broken, most of the tympanic part of the cochlear duct is not preserved. The complete turns of the cochlea are therefore not visible in this specimen, but they were likely approaching those observed in P. cuvieri (approximately 1.6 turns). Only two extant marsupials have such a low number of cochlear turns: the marsupial mole, Notoryctes typhlops (Stirling 1889), and the wombat, Vombatus ursinus (Shaw 1800) (see Horovitz et al. 2008). Two fossil metatherians also exhibit a similar number of turns: Herpetotherium cf. fugax (1.6) and the Montana metatherian described by Meng \& Fox (1995) (1.5).

The bony spiral laminae, which supported the spiral organ of hearing in life, are visible on the cochlear canal, as in most therians (e.g., Meng and Fox, 1995; Luo et al. 2011) and as described for $P$. cuvieri. The primary bony lamina projects from the inner wall of the cochlear canal and extends along most of the cochlear canal length. The secondary bony lamina projects from the outer wall of the cochlear canal and is distinct at the beginning of the first turn. It only extends the first half of the basal turn of the cochlea.

The bony canaliculus cochleae for the cochlear aqueduct is hardly visible on the CT images. It could only be partly reconstructed and it extends as a straight tube from the swelling for the perilymphatic sac, behind the fenestra cochleae (see Supplementary Material 6 for a 3D rendering of the perilymphatic and endolymphatic sacs and aqueducts in P. elegans, $P$. cuvieri and A. minutum).

The semicircular canals of the bony labyrinth of P. elegans are very similar in shape and diameter than those observed in P. cuvieri. The anterior semicircular canal (ASC) exhibits the widest area (expressed as the radius of curvature), as compared to the posterior semicircular canal (PSC), which is also wider than the lateral semicircular canal (LSC) (Fig. 1, Table 1). The LSC plane is perpendicular to the planes of the two other canals $\left(89^{\circ}\right.$ to $\mathrm{ASC}$ and $90^{\circ}$ to 
PSC). The planes of the PSC and ASC form a more open angle $\left(112^{\circ}\right)$. Both these canals meet at the crus commune. The LSC and PSC meet at the second crus commune.

The vestibule is the central area of the bony labyrinth. It is located between the cochlea (anteriorly) and the semicircular canals (posteriorly). The 3D model of the vestibule of $P$. elegans is a very small -much smaller than that of $P$. cuvieri- and irregular structure, which exhibits three bulges located at the junction between the vestibule and the canals: the ampullae. However, the vestibule of $P$. elegans does not clearly display the typical division into the spherical recess (for the saccule) inferiorly and the elliptical recess (for the utricle plus semicircular ducts) superiorly (see Ekdale 2013). The bony channel for the vestibular aqueduct could only be partly reconstructed, it probably exited the vestibule ventral and anterior to the common crus (Supplementary Material 6). The channel extends dorsally and posteriorly, crossing the common crus in medial view, as a slender and straight tube before widening as it curves medially and becomes flattened at the level of the endolymphatic sac (Supplementary Material 6).

The anterior ampulla lies dorsolateral to the vestibule; it connects the ASC to the vestibule. The lateral ampulla lies ventrolateral to the vestibule and connects the LSC to the vestibule. The posterior ampulla lies ventromedial to the vestibule and connects the crus commune to the vestibule.

Amphiperatherium Filhol, 1879

Amphiperatherium minutum (Aymard 1846)

(Fig. 2)

Lectotype. PAR 8.20 Aymard Collection, Musée Crozatier du Puy-en-Velay, France: left mandible with $\mathrm{p} 3-\mathrm{m} 4$ and imprints of c-p2 on the matrix. 
Type locality. Ronzon, France

Age. Late Eocene to middle Oligocene.

Emended diagnosis (modified from Crochet 1980). Small-sized Amphiperatherium, with upper molars (M2 and M3) relatively larger than in A. giselense. Molars of A. minutum are characterised by: very slight size increase from M1 to M3, ectoflexus present but moderate and asymmetrical, stylar cusp C almost always present, stylar cusp B smaller or subequal to the paracone, metastylar area enlarges on $\mathrm{M} 2$ and $\mathrm{M} 3, \mathrm{~m} 2$ and $\mathrm{m} 3$ sub-equal in length, $\mathrm{m} 4$ of same length or slightly shorter than m3. Petrosals are characterised by: absence of caudal tympanic process anterior extension, absence of mastoid process.

\section{Anatomical description of the petrosal bone (MNHN GY682)}

Tympanic view. The petrosal bone of A. minutum is better preserved than that of P. elegans described above, especially in its ventral part (Fig. 2 and Supplementary Material 4). The overall morphology of the tympanic surface is similar to that of the other herpetotheriids. The promontory of A. minutum is strongly inflated and almost hemispherical so that its bulbous part houses the main part of the pars cochlearis. It more resembles in this respect that of $P$. cuvieri than that $P$. elegans, which is apparently less inflated (although this poorly inflated aspect could be due to its bad preservation). The apex of the promontorium is a thin shelf of bone that exhibits in its lateral border a distinct elongated fossa probably for the tensor tympani muscle. It is similar in morphology and location to that observed in Peratherium cuvieri and it is distinctly less shallow than that of P. elegans. A. minutum significantly differs from Herpetotherium cf. fugax the promontorium of which is not as bulbous with a wider anterior apex and a shallower fossa for the tensor tympani muscle. Furthermore, the lateral flange of A. minutum is less expanded than that of $H$. cf fugax, but this could be due to its younger age. As in other herpetotheriids, the promontory of A. minutum bears a small hump in 
its posteromedial region, the rostral tympanic process. The cochlear fossula that contains the fenestra cochleae is larger and more anterior located than in P. cuvieri. It is roughly rounded and differs from the oval-shaped fenestrae of $P$. cuvieri and $H$. cf. fugax, a difference that may be the result of some post mortem breakage. The fenestrae vestibuli of A. minutum exhibits a stapedial ratio of 1.57 , which is close to that of $H$. cf. fugax (1.54) but differs from that of $P$. cuvieri (1.76) whose fenestra vestibuli is distinctly more oval-shaped. As in P. cuvieri and $P$. elegans, the secondary facial foramen of $A$. minutum is lateral and closely approximated to the fenestra vestibuli, whereas it is anterolateral to and well separated from the fenestra vestibuli in $H$. cf. fugax. In the latter, the secondary facial foramen is apart from the epitympanic recess and no crest separates the two structures. In A. minutum, as in the two Peratherium species, the fossa for the epitympanic recess and fossa incudis is bordered by walls and crests a condition which accentuate its deepth. On the contrary, the fossa appears shallower in $H$. cf. fugax. The tympanic petrosal crest of A. minutum is sharp and ventrally covers the tympanic exit of the prootic canal vein and forms the anterior border of the epitympanic recess as in $P$. cuvieri and $P$. elegans. In $H$. cf. fugax the tympanic petrosal crest is conspicuous with a welldeveloped tuberculum tympani. The tympanic petrosal crest of $A$ minutum is more horizontal than in P. elegans and $H$. cf. fugax and, apparently, the tuberculum tympani was poorly developed. The lateral wall of the epitympanic recess is tall as in Peratherium but in contrast to the condition of $H$. cf. fugax in which it is faded. In A. minutum, P. cuvieri, and P. elegans, the crista parotica is sharp and extends medially to form a tall ventrally directed wall, at the top of which lies a faint tympanohyal followed by a shallow stylomastoid notch. On the contrary in $H$. cf. fugax, the crista parotica is not as sharp, and bears a prominent tympanohyal followed by a pronounced stylomastoid notch. In A. minutum, dorsal to the crista parotica and caudal tympanic process, is a very large and superficial stapedial fossa. This contrasts with the condition observed in the two species of Peratherium, in which the stapedial fossa is deep 
and ventrally covered by the caudal tympanic process, which closely approximates the posterior edge of the promontory. The condition of $H$. cf. fugax is intermediate, the stapedial fossa is deep but not covered by the caudal tympanic process. The postpromontorial tympanic sinus is open and large in A. minutum, whereas it is very narrow in both Peratherium species and $H$. cf. fugax. The mastoid process of $A$. minutum is small and low, while it is very prominent in the other herpetotheriids, although less prominent in $H$. cf. fugax than in the two Peratherium species. Sulci for diploetic vessels on the lateral aspect of the petrosal articulating with the squamosal have not been observed on the petrosals of herpetotheriids available during this study.

Cerebellar view. In this view (Fig. 2B), the petrosal of A. minutum is elongated and roughly 8-shaped. It resembles the condition of $H$. cf. fugax, in which it is even more slender, while it is more rounded in P. elegans and cuvieri. The bony shelf separating the FSA and IAM is broad and flat in A. minutum, P. elegans and P. cuvieri, thus differing from the sharp crest that joins the prefacial commissure to the crus commune in H. cf. fugax. In A. minutum, the IAM is broader than the FSA, in contrast to the three other herpetotheriids, in which it is narrower.

The large IAM of A. minutum is characterised by a broad transverse septum that separates the foramen acusticum superius and inferius. In $H$. cf. fugax, the IAM and its transverse septum are also large but not as large as in A. minutum, whereas they are narrower in the two Peratherium species. The prefacial commissure in A. minutum is less extended than in the two Peratherium species and forms a thin bony wall rather than a wide bridge as in P. cuvieri. Therefore, the cavum supracochleare, the intrapetrosal space containing the geniculate ganglion, is less covered. The cavum supracochleare is even more uncovered in $H$. cf. fugax, in which the prefacial commissure is large but far from the center of the petrosal and forms a 
laterally directed handle. The secondary facial foramen is therefore directly visible from the cerebellar view in $H$. cf. fugax, because of the dorsal opening of the cavum supracochleare. The hiatus Fallopii for the exit of the great petrosal nerve is in an intermediate position (anteriorly facing) in P. elegans and P. cuvieri, whereas it is dorsal in A. minutum and $H$. cf. fugax.

In the four herpetotheriid species, the FSA is conical and its aperture is the largest relative to the petrosal width in $H$. cf. fugax, followed by A. minutum, while it is narrower (approximately half the width of the petrosal) in the two Peratherium species. The underlying bony labyrinth, especially the ampulae and crus commune, is more noticeable in A. minutum than in any other herpetotheriids. A s a matter of fact, and probably because of its young ontogenetic stage, the bone surrounding the FSA is very thin and imprints the shape of the inner bony labyrinth: the anterior ampulla, ASC, PSC, and LSC are particularly well visible. In A. minutum, the crista petrosa forms a thin crest that borders laterally the FSA as $\mathrm{f}$ ar as the prefacial commissure. The crista petrosa is not as sharp, does not dorsally covers the most lateral part of the FSA, and does not connect with the prefacial commissure in the three other herpetotheriids. The crista petrosa is even more rounded in the two Peratherium species than in $H$. cf. fugax. The imprint of the superior petrosal sinus at the posterolateral corner of the FSA is superficial in A. minutum and $H$. cf. fugax, compared to the two Peratherium species, in which the sulcus is more pronounced. At the posteriormost tip of the FSA is a thin, posteriorly stretched bony lamina in A. minutum as in $H$. cf. fugax. Such feature is not present in any of the two Peratherium species.

Lateral view. Lateral to the IAM and FSA (Fig. 2B, C), and medially bordered by the sharp crista petrosa and prefacial commissure, lies a triangular and concave thin bony extension, which is interpreted as a relic of the anterior lamina. This structure is more prominent in $A$. 
minutum than in $P$. cuvieri. It is clearly less developed on the specimen of $P$. elegans described here (PAR 39.22) a condition that may be due to incomplete preservation. $H$. cf. fugax does not exhibit any comparable feature. The dorsal aspect of the anterior lamina forms a deep and wide fossa, the trigeminal fossa, which received the trigeminal ganglion (or part of it) during life (Muizon et al. 2018).

In lateral view, the cerebellar surface of the petrosal of $A$. minutum appears planar; in other words, the openings of the IAM and FAS are almost in the same plane: with the opening of the IAM oriented dorsally, the opening of the FAS is barely visible laterally. A similar condition is present in P. elegans. In contrast, the cerebellar surface of the petrosal of $H$. cf. fugax is twisted with the aperture of the FSA laterally directed when the aperture of the IAM is dorsally directed. Such a torsion is also observed in P. cuvieri, but to a lesser extent, while it is absent in A. minutum and P. elegans.

In all the studied herpetotheriids, the bifurcation of the superior petrosal from the transverse and prootic sinuses is observed as a notch in the posterolateral angle of the FSA. This sulcus for the superior petrosal sinus is present in A. minutum but clearly less developed than in $H$. cf. fugax and P. cuvieri. In the four species, the sulcus for the sigmoid sinus, emitted by the transverse sinus at the level of the posterolateral angle of the FSA, borders the FSA posteriorly until its posteromedial angle. In A. minutum, as in $H$. cf. fugax, the sulcus for the sigmoid sinus runs dorsally to the thin bony lamina posterior to the FSA and prints a notch at the posteromedial angle of the FSA. In A. minutum and the two Peratherium species the sulcus for the prootic sinus runs along the posteroventral aspect of the vestigial anterior lamina. In $H$. cf. fugax the sulcus for the prootic sinus borders the lateral surface of the petrosal where it leaves a broad imprint. At the ventral end of the sulcus for the prootic sinus is a small foramen, which is the lateral opening of the prootic canal, which conveys the vein 
of the prootic canal to the lateral head vein in the facial sulcus. A prootic canal in present in the two Peratherium species considered here but is apparently absent in $H$. cf. fugax.

\section{Anatomical description of the bony labyrinth of the inner ear}

The bony labyrinth of the inner ear of $A$. minutum is much better preserved than that of $P$. elegans, especially the cochlear duct (Fig. 2 and Supplementary Material 4), but except for the perilymphatic and endolymphatic bony channels, which are badly preserved. The cochlea completes approximately 1.6 turns, similarly to the other herpetotheriids, and the secondary bony lamina extends along the radial wall of the cochlear canal just beyond the first turn of the cochlea. As observed in $P$. cuvieri, $P$. elegans, and $H$. cf fugax, the radius of curvature of the ASC is the most important, followed by that of PSC and then LSC. However, the radii calculated for A. minutum are lesser than those of the two Peratherium species, but higher than those of $H$. cf. fugax.

In A. minutum, the plane containing the LSC is not perpendicular (less than $90^{\circ}$ ) to the two other planes: it is inclined towards the crus commune. The latter is broad and short while it is longer and narrower in the three other herpetotheriids. The four herpetotheriids exhibit a secondary crus commune.

The vestibule of $A$. minutum is roughly more globular and less stretched than that of $P$. cuvieri. The lateral ampulla especially is globular and closer to the vestibule as compared to the Peratherium species, in which it is stretched and extended externally.

The spherical and elliptical recesses of the vestibule are distinguished by a constriction of the vestibule lateral to the fenestra vestibuli: the swelling of the spherical recess is visible in anterior view of the labyrinth and the elliptical recess is bowed slightly medially to it (Fig. 2A,C). 


\section{Phylogenetic analysis}

The parsimony analysis resulted in two shortest trees $(\mathrm{L}=982, \mathrm{CI}=0.5, \mathrm{RI}=0.62$; see Supplementary Material 7). The phylogenetic relationships within Metatheria exhibited in the strict consensus tree $(\mathrm{L}=985, \mathrm{CI}=0.5, \mathrm{RI}=0.62$; Fig. 3$)$ are relatively consensual when compared to generally accepted hypotheses, although the latter reached no consensus about the placement of peradectids and herpetotheriids (e.g., Horovitz et al. 2009; Beck 2012; Beck et al. 2014; Wilson et al. 2016). In the present topology, peradectids are sister group to the clade comprising stagodontids, pucadelphyids, sparassodonts, herpetotheriids, and Marsupialia. This grouping of peradectids, in a paraphyletic gathering of early marsupialiforms, stem to Marsupialia is congruent with the phylogenetic results of Beck (2012), Beck et al. (2014) but contrary to that of Horovitz et al. (2009), who found peradectids closely related to didelphids, and Wilson et al. (2016), who retreived peradectids with Herpetotherium in a clade sister group to Marsupialia. Here we evidence the close relationship of herpetotheriids with the crown clade Marsupialia, which was previously advanced by Sánchez-Villagra et al. (2007). But interestingly, as retrieved by Muizon et al. (2018), herpetotheriids do not form a monophyletic assemblage, since Herpetotherium is the sister taxon to Marsupialia, forming a clade to which is linked the clade comprising the european herpetotheriids Amphiperatherium and Peratherium.

Here we focus on the clades of interest (i.e., regarding herpetotheriids relationships), and a detailed list of synapomorphies is available in Supplementary Material 7. Herpetotheriids result closer to the crown group Marsupialia than to any other marsupialiformes. This clade is supported by five unambiguous synapomorphies and a Bremer decay index of 3 (relative to a mean of 4). Considering the total number of 
synapomorphies, most of them are from the postcranium (16), while 12 are dental and 10 cranial (including three from the ear region).

The sister group relationship of Herpetotherium and Marsupialia is supported by four unambiguous synapomorphies and a low Bremer decay index of 1 (relative to a mean of 4). A total of 16 unambiguous and ambiguous synapomorphies support this clade, with seven dental, six cranial (including 4 from the ear region), and three postcranial synapomorphies. The clade including the three European herpetotheriids of this study (i.e., $\underline{\text { Amphiperatherium }}$ minutum, Peratherium cuvieri, and Peratherium elegans) is supported by two unambiguous synapomorphies and a low Bremer decay index of 1 (relative to a mean of 4). It is defined by seven dental, five cranial (including three from the ear region), and one postcranial unambiguous and ambiguous synapomorphies.

The sister group relationship of Peratherium cuvieri and P. elegans is supported by one unambiguous synapomorphy and a low Bremer decay index of 1 (relative to a mean of 4). It is noteworthy that only cranial synapomorphies (three among which two from the ear region) support this clade.

\section{Discussion}

Herpetotheriids have been traditionally included into or closely related to didelphimorphs or didelphoids, mostly based on dental similarities but also some cranial features (e.g., Simpson 1945; Crochet 1980; Reig et al. 1987; Marshall 1990; Korth 1994; Gabbert 1998; Case et al. 2005). Krishtalka \& Stucky (1983a) stated that such a relationship (i.e., herpetotheriids included within the tribe Didelphini) was rather based on primitive features as compared to the derived dental features of Peradectini. The present work suggests a different evolutionary scenario, in which herpetotheriids clearly exhibit more derived characters than peradectids but 
do not share any apomorphic features with extant didelphimorphs. According to our results herpetotheriids are sister group of Marsupialia but are not included in this clade.

Sister group relationship to Marsupialia was already suggested by some recent phylogenies (e.g., Sanchez-Villagra et al. 2007; Horovitz et al. 2009; Forasiepi 2009; Beck et al. 2014; Oliveria \& Goin 2015; Wilson et al. 2016; Lorente et al. 2016; Carneiro 2018 -all of these studies including Herpetotherium only), although such analyses did not agree on the relationships of herpetotheriids, peradectids, and other metatherians; the phylogenetic affinities among herpetotheriids have only been tested by fossil-exclusive analyses (Williamson et al. 2012, only american taxa). The relationships of herpetotheriids retrieved in our analysis is congruent with the result of Muizon et al. (2018).

We find that herpetotheriids and Marsupialia share six strict synapomorphies: long epipubic bones (ch237-1), absence of posterior process of pterygoids, which covers the alisphenoidbasisphenoid suture (ch121-1 -Acctran), paroccipital process larger than posttympanic process (ch169-0 -Acctran), atlas and intercentrum fused (ch193-1 -Acctran), dorsal head of C5 transverse process well posterior to and not overhanging ventral head in lateral view (ch198-1 -Acctran), and ungual phalange uncleft (ch285-1 -Acctran).

Our result highlights the paraphyly of herpetotheriids, Herpetotherium being more closely related to Marsupialia than to the European herpetotheriids. We therefore propose here to maintain the concept of Herpetotheriidae (althought paraphyletic it is of historical importance), and to name the clade European herpetotheriids Peratherinae and the clade including Herpetotherium and any of its potential relatives Herpetotheriinae. Interestingly, some of the synapomorphies shared by Herpetotherium and Marsupialia are lost in didelphids; for instance, the postmetacrista subequal or shorter than preparacrista (ch29-0), and the stylar cusp B vestigial to absent (ch32-2). 
The present study has highlighted interesting differences between the North American genus and the two European genera of herpetotheriids. The close relationship of Herpetotherium and Marsupialia is supported by two unambigous petrosal synapomorphies: the anterior lamina of the petrosal is absent (ch155-1) whereas present but rudimentary in Peratherium and Amphiperatherium; the tuberculum tympani is expanded into a sharp anteroventrally directed process (ch177-1) while it is a bulge in Peratherium and Amphiperatherium. Furthermore, other petrosal features separates Herpetotherium from the Peratheriinae: the rostral tympanic process is an anterolaterally directed wing on the posteromedial region of promontorium -as in Didelphinae (ch165-1), while it forms a simple knob with a restricted anterior edge in Peratherium and Amphiperatherium; the diameter of stapedius fossa is distinctly less than twice the size of that of the fenestra vestibuli (=small and shallow) - as in most didelphids except Metachirus (ch170-1) - while it is larger in Peratherium and Amphiperatherium. The molar characters that are shared between Herpetotherium and Marsupialia are the following: diastema posterior to first upper premolar present (ch16-1) (convergent with Asiatherium, Sipalocyon, and variable in pucadelphyids); hypoconid at posterolabial angle of tooth (ch71-1) (convergent with peradectids).

It is noteworthy that the specimens conferred to as Herpetotherium fugax are two skulls with petrosals, and that this assignment was based on dental characters, and more particularly from the stylar shelf of upper molars (Sánchez-Villagra et al. 2007; Horovitz et al. 2008). The stylar shelf being not involved in the shear pattern during mastication (Crompton \& Hiiemae 1970; Ladevèze et al. 2012), it is consequently more subject to variations due to less functional constraint and is regarded as somewhat doubtful for systematic diagnoses. From its petrosal anatomy, the specimen here studied of $H$. cf. fugax appears very different from other 
herpetotheriids and not closely related to the clade gathering Peratherium and Amphiperatherium.

European herpetotheriids (including the genera Peratherium and Amphiperatherium), are defined by two strict synapomorphies: the internal acoustic meatus and fossa subarcuata are subequal and separated by thick wall (ch158-1), and the presence of one palatal pit (between ultimate and penultimate molar) (ch114-1) (but only verified in P. cuvieri). It is noteworthy that an ossified patella is here identified in the Peratherium cuvieri specimen from the Montmartre gypsum (ch240-1). An ossified patella occurs in monotremes and eutherians but has been lost in many marsupials (see Samuels 2017) (convergent with sparassodonts actually only Sipalocyon).

Herpetotheriidae have been traditionally gathered based on the following molar characters (by opposition to those found in Peradectidae; see Krishtalka \& Stucky 1983a, b): tall and spirelike entoconid; much lower, posteriorly projecting hypoconulids; deep and wide entoconid notches; posteriorly expanded protocone; strong conules and stylar cusp C; dilambdodonty; and paracone lower than metacone. More recently, Williamson et al. (2012) found only one synapomorphy of Herpetotheriidae: the centrocrista is deflected buccally so that it is Vshaped. Here, only one of the diagnostic characters of herpetotheriids is one synapomorphy of the clade uniting Amphiperatherium and Peratherium: the conical entoconid (ch72-0 Deltran) (= reversion from Metatheria; convergent with Dromiciops, pucadelphyids, and Asiatherium).

It is noteworthy that two of the synapomorphies of the clade Peratheriinae are also found in Herpetotherium: fossa subarcuata cylindrical to conical (greatest diameter subequal to aperture) (ch159-1 -Deltran) (convergent with Didelphis and Herpetotherium); long skull 
(more than twice width at level of zygomatic arch) (ch90-1 -Deltran) (convergent with Didelphis, Metachirus, Herpetotherium, and Andinodelphys). Furthermore, the latter and another synapomorphy of the European herpetotheriids can alternatively be optimised at the clade uniting all herpetotheriids and Marsupialia: ultimate upper molar narrower in labiolingual width than penultimate upper molar (ch25-0 -Deltran).

The two European herpetotheriid genera appear difficult to distinguish. The only undoubtful differences between Peratherium and Amphiperatherium are from the petrosal anatomy. The genus Peratherium is characterized by two petrosal synapomorphies: intermediate (i.e. anterior) tympanic aperture of hiatus Fallopii (ch172-1) (dorsal in A. minutum), and anteriorly extended caudal tympanic process that floors the postpromontorial sinus (ch166-1 -Deltran) (caudal tympanic process not extended in A. minutum). Two autapomorphies define Amphiperatherium: mastoid process indistict to absent (ch171-1), while it is a small nodular tubercle on posterolateral border of stylomastoid notch in Peratherium; caudal tympanic process not anteriorly extended (ch166-0 -Acctran), contrary to the condition observed in Peratherium.

It is noteworthy that if we consider the molar morphology, the features observed in Peratherium cuvieri are retrieved in the genus diagnosis but not all are consistent with the species diagnosis (Crochet, 1980). In the studied specimen of P. cuvieri (the holotype), the stylar cusp C is not distinguishable on the M2 and only slightly recognizable on the M3, whereas the diagnosis states the presence of an isolated stC. The ectoflexus is slightly dissemetrical on the M2, whereas noted as symmetrical in the diagnosis. The two species of Peratherium differ in: the stylar cusp $\mathrm{C}$ is prominent in P. elegans and indistinguishable in P. cuvieri; the ectoflexus is shallower in P. elegans; the preparacrista ends between the stylar cusps A and B in P. elegans while it ends at stA in P. cuvieri; the 
protocone is strongly projected anteriorly in P. elegans. These differences are yet not mentioned as distinct attributes between the two species in their diagnoses. The diagnoses, which highlight the strong resemblance between the two species, contain differences that are not all observable on the chosen specimens. For instance, the features of the stylar cusps or the ectoflexus are not consistent with the diagnosis in the specimen of $P$. cuvieri studied here. Therefore, the delimitation of the two species appears vague and their diagnostic characters are not all found on the holotypes. It is noteworthy that the diagnoses indicate an important morphological variability inside the species, and the terms "more or less", "generally", and "sometimes" are widely used.

The main differences observed between Peratherium and Amphiperatherium are: more slender cusps in Amphiperatherium; the postmetacrista is a tall wall in Amphiperatherium, while it is not distinguishable in Peratherium. As noted above, some of the features listed in the diagnoses are not observable in the studied specimens.

The paraphyly of herpetotheriids in a stem placement to the crown Marsupialia, and the early divergence of European herpetotheriids suggest a Laurasiatic origin of the clade comprising herpetotheriids and Marsupialia. Moreover, the close relationships of Herpetotherium and the crown Marsupialia and the occurrence of herpetotheriids such as Nortedelphys in the Lancian (late Maastrichtian) of North America (Alberta, Wyoming, and Montana; Case et al. 2005) as well as Swaindelphys in the early Palaeocene (late Torrejonian-To2) of North America (Johanson 1996; Williamson \& Taylor 2011: fig 2) advocates for a North American origin of the clade during the Late Cretaceous. A first dispersal event of members of this clade to South America occurred at this time (Late Cretaceous); another may have occurred during the early Palaeocene but probably no later (Goin et al. 2016: 214; Muizon et al. 2018). As a matter of fact, herpetotheriids have been recorded in South America. Goin \& Candela (2004) have 
referred the late Eocene genus Rumiodon (Santa Rosa, Peru) to cf. family Herpetotheriidae and Oliveira \& Goin (2012) have referred several taxa from the early Eocene of Itaboraí (Brazil) to the family (e.g., Didelphopsis, Itaboraidelphys, Carolopaulacoutoia). Goin et al. (2016: Table 5.1, p. 160) included the family in their classification of Cenozoic South American taxa, but with no genus referred to it. Moreover, if one follows Goin et al. (2016) in including the Polydolopimorphia in the Marsupialia (which we do), the supercohort is represented in the earliest Palaeocene of South America by the polydolopiform Cocatherium lefipanum from the Grenier Farm locality (Paso del Sapo area, Chubut province, Argentina; Goin et al. 2006). In fact, Cocatherium is even the oldest record of a therian mammal of South America. This single lower molar therefore suggests a Late Cretaceous arrival of the Marsupialia to South America. Another dispersal event to Europe took place at the latest in the early Eocene and possibly earlier since Peratherium is present in the basal Eocene (Wasatchian, Wa0) of North America (Strait 2001). Furthermore, if the herpetotheriid affinities of Maastrichtidelphys from the Late Maastrichtian of the Netherlands is confirmed, at least one dispersal event to Europe occurred well before the Eocene.

\section{Conclusions}

The clade comprising the three European taxa A. minutum, $P$. cuvieri, and P. elegans, which we propose here to name Peratheriinae, is supported by a few number of dental synapomorphies, while both Peratherium species share petrosal characteristics: internal acoustic meatus and fossa subarcuata subequal and separated by a sharp wall; anterior extension of the caudal tympanic process of petrosal. 
Herpetotherium is the closest fossil relative to the extant clade Marsupialia as they share derived features from the petrosal bone: absence of an anterior lamina of the petrosal (which remains vestigial in Peratheriinae); rostral tympanic process of petrosal forms an anterolaterally directed wing, restricted to the posterior region of the promontorium (no wing in Peratheriinae); a narrow stapedius fossa (larger in Peratheriinae, almost twice the size of the fenestra vestibuli); a tuberculum tympani forming an anteroventrally directed process (bulge in Peratheriinae).

Contrary to the previous concepts of Didelphimorphia (e.g., Kirch et al. 1997) and contrary to the phylogenetic hypothesis of Horovitz et al. (2009), neither herpetotheriids nor peradectids are sister group to extant opossums (didelphids). Therefore, and as suggested by SánchezVillagra et al. (2007), there is a major gap in the fossil record of opossums, the time estimate for their origin being found in the mid-late Palaeocene by molecular studies (Jansa et al. 2014; Vilela et al. 2015) (but see Duchêne et al. 2018 for a younger estimation in the Oligocene).

The phylogenetic placement of Herpetotherium implies a paleobiogeographic scenario of a North American ancestral stock of stem marsupials that gave rise to the radiation of Marsupialia in South America, most probably during the early Palaeocene.

\section{Acknowledgements}

This work was supported by the MNHN grants “ATM Formes possibles, Formes réalisées, 2014" and "PPF Etat et structure phylogénétique de la biodiversité actuelle et fossile, 2008". 
We would like to thank Christine Argot for the access to the mammal collections of

Paleontology, Emmanuel Magne (Musée Crozatier) for providing access to the specimen of Peratherium elegans, the AST-RX platform of the MNHN, the University Center for Quantitative X-ray Imaging, Penn State, and the Atelier 3D of the CR2P MNHN.

Finally, we warmly thank the two reviewers, Loïc Costeur and Brian Davis, who greatly improved the manuscript. 


\section{Supplementary Materials}

SM1- List of Character states

SM2- Taxon/Character Matrix

SM3-3D PDF file of the 3D rendering of CT data of the petrosal and inner ear of Peratherium elegans (PAR 39.22)

SM4- 3D PDF file of the 3D rendering of CT data of the petrosal and inner ear of Amphiperatherium minitum (MNHN GY682)

SM5- Visualisation of the prootic canal of Herpetotherium cf. fugax (ZMB 50672)

SM6- 3D reconstruction of the perilymphatic end endolymphatic bony channels and sacs of Peratherium cuvieri (MNHN-GY-679), P. elegans (PAR 39.22), and Amphiperatherium minutum (MNHN GY682)

SM7- Results of the Parsimony analysis 


\section{References}

Abramoff, M.D., Magalhães, P. J., Ram, S. J. 2004. Image processing with ImageJ. Biophotonics international, 11(7), 36-42.

Beck, R. M. D. 2012. An 'ameridelphian' marsupial from the early Eocene of Australia supports a complex model of Southern Hemisphere marsupial biogeography. Naturwissenschaften, 99, 715-729.

Beck R., Travouillon K. J., Aplin K. P., Godthelp H. \& Archer M. 2014. The osteology and systematics of the enigmatic Australian Oligo-Miocene metatherian Yalkaparidon (Yalkaparidontidae; Yalkaparidontia; ?Australidelphia; Marsupialia). Journal of Mammalian Evolution, 21, 127-172.

Billet, G., Germain, D., Ruf, I., de Muizon, C. \& Hautier, L. 2013. The inner ear of Megatherium and the evolution of the vestibular system in sloths. Journal of Anatomy, 223, $557-567$.

Blanks, R. H. I., Curthoys, I. S. \& Markham, C. H. 1975. Planar relationships of the semicircular canals in man. Acta of Oto-Laryngology, 80, 185-196.

Bremer, K. 1988. The limits of amino acid sequence data in angiosperm phylogenetic reconstruction. Evolution, 42(4), 795-803.

Carneiro, L. M. 2018. A new species of Varalphadon (Mammalia, Metatheria, Sparassodonta) from the upper Cenomanian of southern Utah, North America: phylogenetic and biogeographic insights. Cretaceous Research, 84, 88-96.

Case, J. A., Goin, F. J. \& Woodburne, M. O. 2005. "South American" marsupials from the Late Cretaceous of North America and the origin of marsupial cohorts. Journal of Mammalian Evolution, 12(3-4), 461-494. 
Crochet J.-Y. 1980. Les Marsupiaux Du Tertiaire d'Europe. Paris: Editions de la Fondation Singer-Polignac, 279 pp.

Crompton, A. W. \& Hiiemae, K. 1970. Molar occlusion and mandibular movements during occlusion in the American opossum, Didelphis marsupialis L. Zoological Journal of the Linnean Society, 49(1), 21-47.

David, R., Droulez, J., Allain, R., Berthoz, A., Janvier, P. \& Bennequin, D. 2010. Motion from the past. A new method to infer vestibular capacities of extinct species. CR Palevol, 9 $397-410$.

Duchêne, D. A., Bragg, J. G., Duchêne, S., Neaves, L. E., Potter, S., Moritz, C., Johnson, R. N., Ho, S. Y. W. \& Eldridge, M. D. B. 2018. Analysis of phylogenomic tree space resolves relationships among marsupial families. Systematic Biology, 67(3): 400-412.

Ekdale, E. G. 2013. Comparative anatomy of the bony labyrinth (inner ear) of placental mammals. PLoS One, 8(6), e66624.

Forasiepi, A. M. 2009. Osteology of Arctodictis sinclairi (Mammalia, Metatheria, Sparassodonta) and phylogeny of Cenozoic metatherian carnivores from South America. Monografías del Museo Argentino de Ciencias Naturales, 6, 1-174.

Forasiepi, A. M., Babot, M. J. \& Zimicz, N. 2015. Australohyaena antiqua (Mammalia, Metatheria, Sparassodonta), a large predator from the late Oligocene of Patagonia. Journal of Systematic Palaeontology, 13(6), 503-525.

Gabbert, S. L. 1998. Basicranial anatomy of Herpetotherium (Marsupialia: Didelphimorphia) from the Eocene of Wyoming. American Museum Novitates, 3235, 1-13.

Goin, F. J. 1991. Los didelphoidea (mammalia: marsupialia) del cenozoico tardío de la región pampeana. Doctoral dissertation, Facultad de Ciencias Naturales y Museo. 
Goin, F. J., \& Candela, A. M. 2004. New paleogene marsupials from the Amazon Basin of eastern Peru. The Paleogene Mammalian Fauna of Santa Rosa, Amazonian Peru. Natural History Museum of Los Angeles County, Science Series, 40, 15-60.

Goin, F. J., Pascual, R., Tejedor, M. F., Gelfo, J. N., Woodburne, M. O., Case, J. A., Reguero, M. A., Bond, M., López, G. M., Cione, A. L., Sauthier, D. U., Balarino, L., Scasso, R. A., Medina, F. A. \& Ubaldón, M. C. 2006. The earliest Tertiary therian mammal from South America. Journal of Vertebrate Paleontology, 26(2), 505-510.

Goin, F. J., Woodburne, M. O., Zimicz, A. N., Martin, G. M. \& Chornogubsky, L. 2016. Phylogeny and diversity of south american metatherians. Pp. 155-184 in F. J. Goin, M. O. Woodburne, A. N. Zimicz, G. Martin \& L. Chornogubsky (eds) A brief history of South American metatherians. Springer Earth System Sciences.

Horovitz, I., Ladevèze, S., Argot, C., Hooker, J. J., Macrini, T. E., Martin, T., Kurz, C., de Muizon, C. \& Sánchez-Villagra, M. R. 2008. The anatomy of Herpetotherium fugax Cope 1873, a metatherian from the Oligocene of North America. Palaeontographica Abteilung A, 284, 109-141.

Horovitz, I., Martin, T., Bloch, J., Ladevèze, S., Kurz, C., Sánchez-Villagra, M. R. 2009. Cranial anatomy of the earliest marsupials and the origin of opossums. PLoS ONE, 4, e8278. Jansa, S. A., Barker, F. K., \& Voss, R. S. 2014. The early diversification history of didelphid marsupials: a window into South America's "Splendid Isolation”. Evolution, 68(3), 684-695.

Johanson, Z. 1996. New marsupial from the Fort Union Formation, Swain Quarry, Wyoming. Journal of Paleontology, 70,1023-1031.

Kirsch, J. A., Springer, M. S., \& Lapointe, F. J. 1997. DNA-hybridisation studies of marsupials and their implications for metatherian classification. Australian Journal of Zoology, 45(3), 211-280. 
van der Klaauw, C. J. 1931. The auditory bulla in some fossil mammals: with a general introduction to this region of the skull. Bulletin of the American Museum of Natural History, LXII, 1-352.

Korth, W. W. 1994. Middle Tertiary marsupials (Mammalia) from North America. Journal of Paleontology, 68(2), 376-397.

Krishtalka, L. \& Stucky, R. K. 1983a. Revision of the Wind River Faunas, early Eocene of Central Wyoming. Marsupialia. Annals of Carnegie Museum, 52, 205-27.

Krishtalka, L. \& Stucky, R. K. 1983b. Paleocene and Eocene marsupials of North America. Annals of Carnegie Museum, 52(10), 229-263.

Ladevèze, S. \& de Muizon, C. 2007. The auditory region of early Paleocene Pucadelphydae (Mammalia, Metatheria) from Tiupampa, Bolivia, with phylogenetic implications. Palaeontology, 50, 1123-1154.

Ladevèze, S. \& de Muizon, C. 2010. Evidence of early evolution of Australidelphia (Metatheria, Mammalia) in South America: phylogenetic relationships of the metatherians from the Late Palaeocene of Itaboraí (Brazil) based on teeth and petrosal bones. Zoological Journal of the Linnean Society, 159, 746-784.

Ladevèze, S., Smith, R. \& Smith, T. 2012. Reassessment of the morphology and taxonomic status of the earliest herpetotheriid marsupials of Europe. Journal of Mammalian Evolution, 19, 249-261.

Lorente, M., Chornogubsky, L. \& Goin, F. J. 2016. On the existence of nonmicrobiotherian australidelphian marsupials (Diprotodontia) in the Eocene of Patagonia. Palaeontology, 59, 533-547.

Marshall, L. G. 1990. Phylogenetic relationships of the families of marsupials. Current Mammalogy, 2, 433-505. 
Marshall, L. G. \& de Muizon C. 1995. Part II. The skull. Pp. 21-90 in C. de Muizon (ed.) Pucadelphys andinus (Marsupialia, Mammalia) from early Paleocene of Bolivia. Mémoires du Muséum national d'Histoire naturelle, Paris, France.

Meng, J. \& Fox, R. C. 1995. Osseous inner ear structures and hearing in early marsupials and placentals. Zoological Journal of the Linnean Society, 115, 47-71.

de Muizon, C., Ladevèze, S., Selva, C., Vignaud, R. \& Goussard, F. 2018. Allqokirus australis (Sparassodonta, Metatheria) from the early Palaeocene of Tiupampa (Bolivia) and the rise of the metatherian carnivorous radiation in South America. Geodiversitas, 40(3), 363459.

Oliveira, É. V. \& Goin, F. J. 2012. Marsupiais do início do Paleógeno no Brasil: diversidade e afinidades. Os marsupiais do Brasil: biologia, ecologia e conservação. Campo Grande, Mato Grosso do Sul, Brasil, 275-307.

Reig, O. A., Kirsch, J. A. W. \& Marshall, L. G. 1987. Systematic relationships of the living and Neocenozoic American 'opossum- like' marsupials (suborder Didelphimorphia), with comments on the classification of these and of the Cretaceous and Paleogene New World and European metatherians. Pp. 1-89 in M. Archer (ed.) Possums and opossums: studies in evolution. Sydney: Surrey Beatty \& Sons and the Royal Zoological Society of New South Wales.

Rougier, G. W. \& Wible, J. R. 2006. Major changes in the ear region and basicranium of early mammals. Pp. 269-311 in M. Carrano, T. J. Gaudin, R. Blob \& J. R. Wible (eds) Amniote paleobiology: phylogenetic and functional perspectives on the evolution of mammals, birds and reptiles. Chicago, IL: University of Chicago Press.

Samuels, M. E., Regnault, S. \& Hutchinson, J. R. 2017. Evolution of the patellar sesamoid bone in mammals. PeerJ, 5, e3103. 
Sánchez-Villagra, M. R., Ladevèze, S., Horovitz, I., Argot, C., Hooker, J. J., Macrini, T., Martin, T., Moore-Fay, S., de Muizon, C., Schmelzle, T. \& Asher, R. J. 2007.

Exceptionally preserved North American Paleogene metatherians: adaptations and discovery of a major gap in the opossum fossil record. Proceedings of the Royal Society, Biology Letters, 3, 318-322.

Selva, C. \& Ladevèze, S. 2017. Computed microtomography investigation of the skull of Cuvier's famous 'opossum' (Marsupialiformes, Herpetotheriidae) from the Eocene of Montmartre. Zoological Journal of the Linnean Society, 180(3), 672-693.

Simpson, G. G. 1945. The principles of classification and a classification of mammals. Bulletin of the American Museum of Natural History, 1(85), 1-350.

Spoor, F. 2003. The semicircular canal system and locomotor behaviour, with special reference to hominin evolution. Courier-Forschungsinstitut Senckenberg, 93-104. Spoor, F., Garland, T., Krovitz, G., Ryan, T. M., Silcox, M. T. \& Walker, A. 2007. The primate semicircular canal system and locomotion. Proceedings of the National Academy of Sciences, 104(26), 10808-10812.

Strait, S. G. 2001. New Wa-0 mammalian fauna from Castle Gardens in the southeastern Bighorn Basin. University of Michigan Papers on Paleontology, 33, 127-143.

Swofford, D. L. 2002. PAUP*: phylogenetic analysis using parsimony, v. 4.0 b10. Sinauer, Sunderland, $M A$.

Vilela, J. F., Alves de Oliveira, J. \& Russo, C. A. D. M. 2015. The diversification of the genus Monodelphis and the chronology of Didelphidae (Didelphimorphia). Zoological Journal of the Linnean Society, 174(2), 414-427.

Wible, J. R. 1990. Petrosals of Late Cretaceous marsupials from North America, and a cladistic analysis of the petrosal in therian mammals. Journal of Vertebrate Paleontology, 10, 183-205. 
Wible, J. R. 2003. On the cranial osteology of the short-tailed opossum Monodelphis brevicaudata (Didelphidae, Marsupialia). Annals of Carnegie Museum, 72, 137-202. Wible J. R. \& Hopson J. A. 1995. Homologies of the prootic canal in mammals and nonmammalian cynodonts. Journal of Vertebrate Paleontology, 15, 331-356.

Wible, J. R., Rougier, G. W., Novacek, M. J. \& Asher, R. J. 2009. The eutherian mammal Maelestes gobiensis from the Late Cretaceous of Mongolia and the phylogeny of Cretaceous Eutheria. Bulletin of the American Museum of Natural History, 327, 1-123.

Williamson, T. E., Brusatte, S. L., Carr, T. D., Weil, A. \& Standhardt, B. R. 2012. The phylogeny and evolution of Cretaceous-Palaeogene metatherians: cladistic analysis and description of new early Palaeocene specimens from the Nacimiento Formation, New Mexico. Journal of Systematic Palaeontology, 10(4), 625-651.

Williamson, T. E. \& Taylor, L. H. 2011. New species of Peradectes and Swaindelphys (Mammalia: Metatheria) from the Early Paleocene (Torrejonian) Nacimiento Formation, San Juan Basin, New Mexico, USA. Palaeontologia Electronica, 14(3), 1-16.

Wilson G. P., Ekdale E. G., Hoganson J. W., Calede J. J. \& Vander Linden A. 2016. A large carnivorous mammal from the Late Cretaceous and the North American origin of marsupials. Nature Communications, 7, 13734. 


\section{Figure captions}

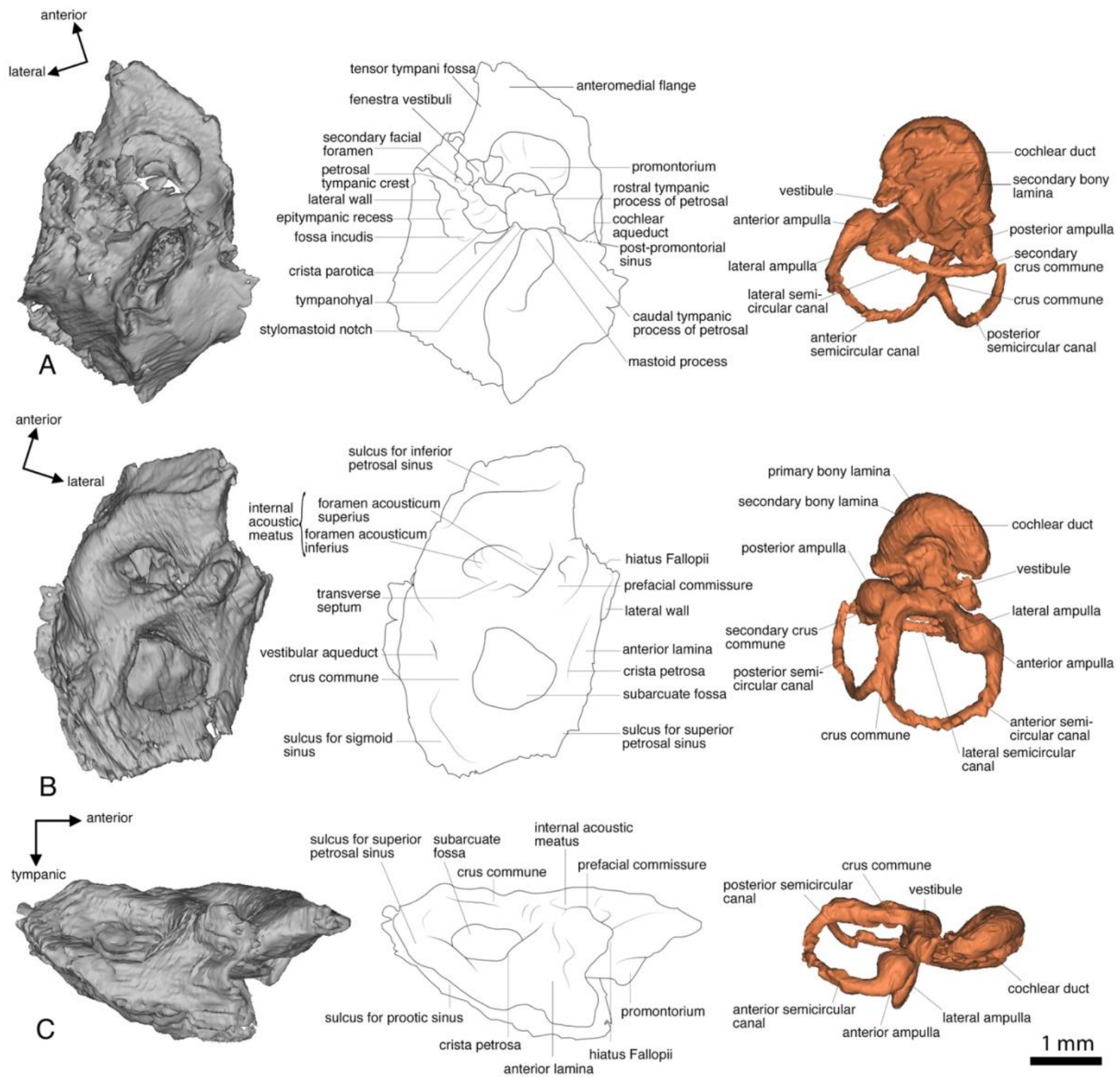

Figure 1. Right petrosal bone and bony labyrinth of Peratherium elegans (PAR 39.22) in ventral (A), endocranial (B), and lateral (C) views. 

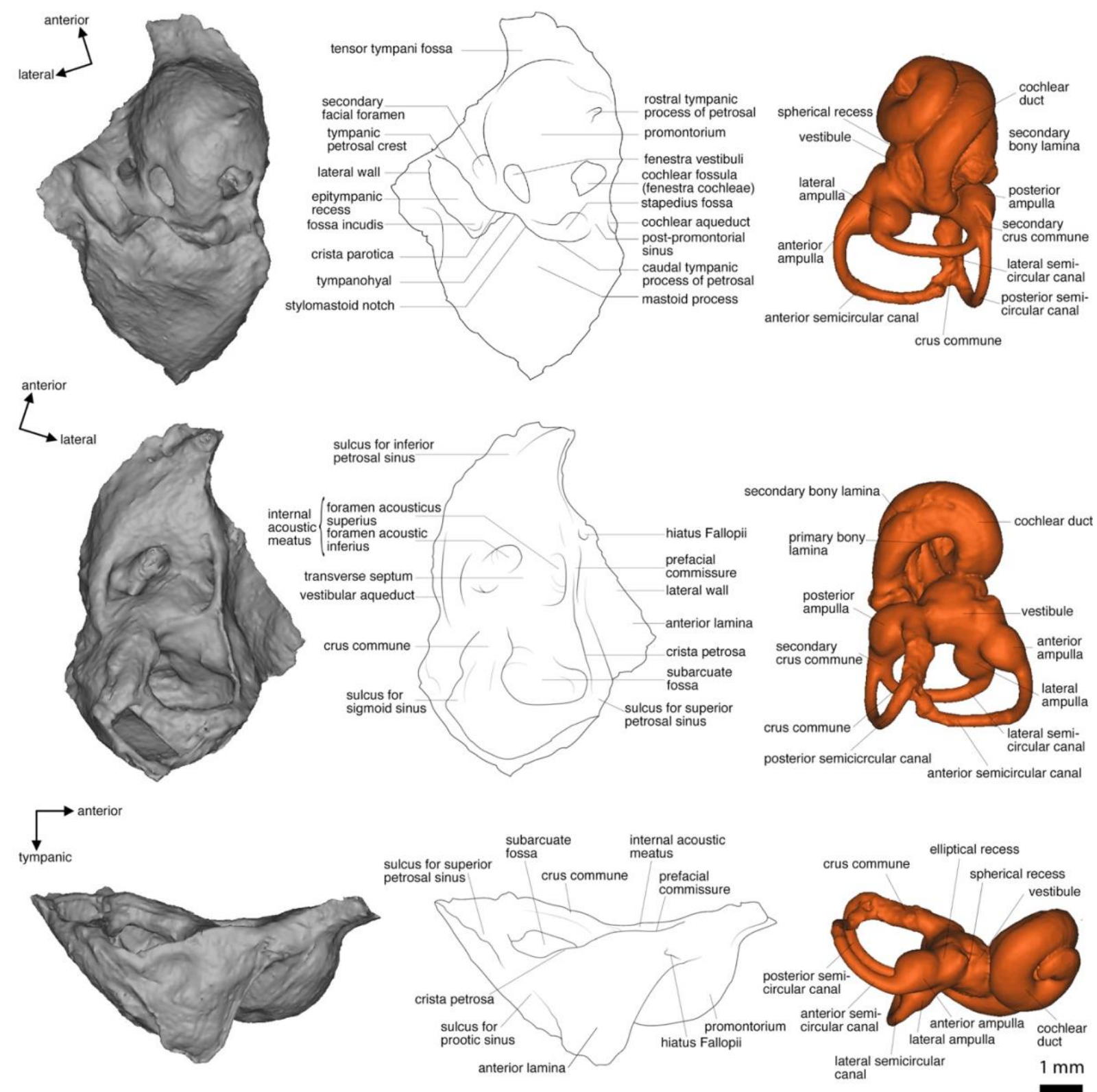

Figure 2. Right petrosal bone and bony labyrinth of Amphiperatherium minutum

(MNHN-GY-682) in ventral (A), endocranial (B), and lateral (C) views. 


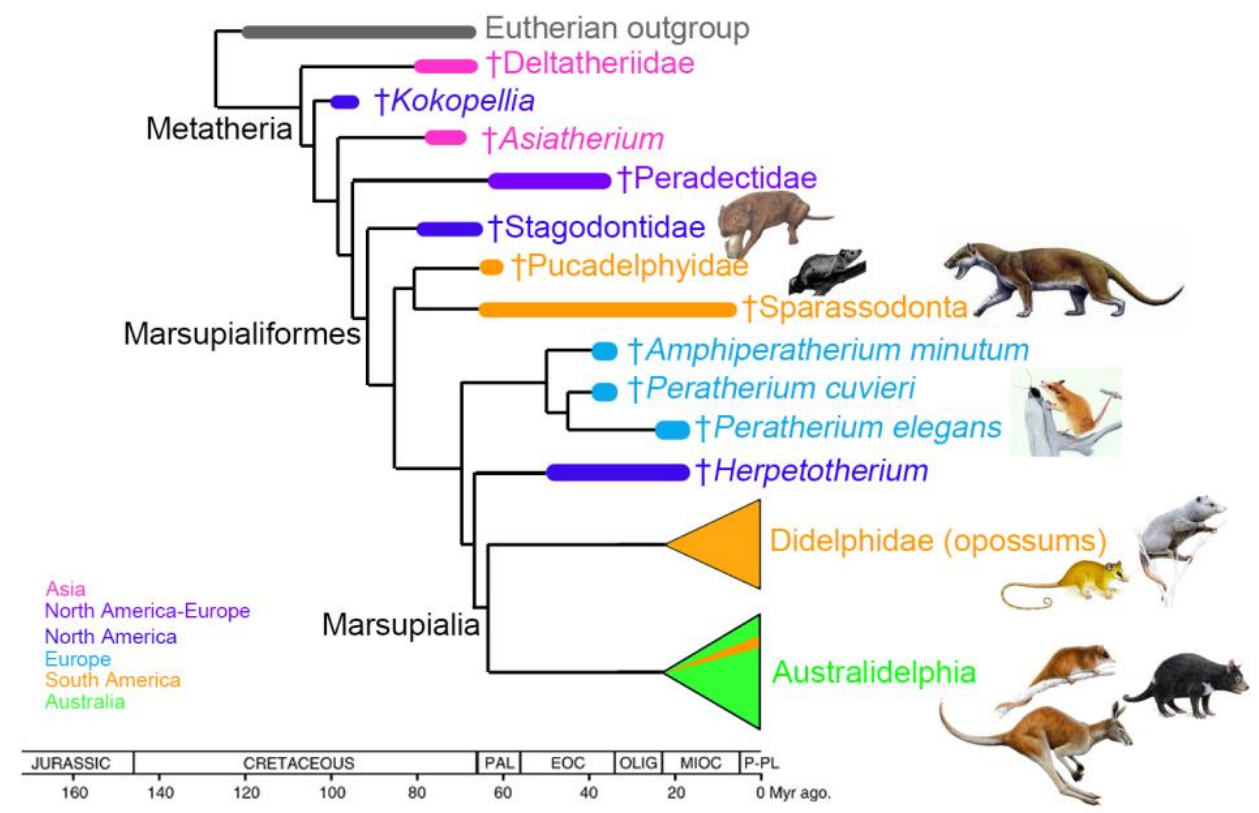

Figure 3. Strict consensus tree $(L=985, C I=0.5, R I=0.62)$ of the two shortest trees resulting from the parsimony analysis, resulting from the analysis of $\mathbf{2 8 6}$ osteological characters and 25 metatherian taxa.

\section{Table caption}

Table 1. Measurements of various semicircular canals aspects, taken in Amphiperatherium minutum, Peratherium elegans, Peratherium cuvieri, Herpetotherium cf fugax, and Marmosa murina. For each semicircular canal (ASC, PSC, LSC), height (H), width (W) and diameter (D) were measured, as well as the angles between each other. The inner ear height (IEH) was measured after Billet et al. (2013). The radius of curvature for each semicircular canal was calculated following Spoor et al. (2007). 